\title{
MAGYARORSZÁG VERSENYKÉPESSÉGE A KÖZÉP-KELET-EURÓPAI SZEKTORBAN
}

\author{
Visontai LUCA \\ Edutus Egyetem volt hallgatója \\ lucav08@gmail.com \\ DOI 10.47273/AP.2020.20.192-203
}

\begin{abstract}
ABSZTRAKT
A rendszerváltást követően a külföldi beruházások és a nyitott gazdasággá válás kelet és nyugat határán jelentősen átformálta a gazdasági folyamatokat a kelet-közép-európai térségben. Az SSC-jellegü vállalkozások és a mai szolgáltató központok kezdetleges formái az 1990-es évek elején jelentek meg Európa-szerte, így Magyarországon is. A kezdetben alacsony hozzáadott értékkel bíró, egyszerü feladatokat ellátó vállalkozások később a hatásköröket és tevékenységeket kiterjesztve többfókuszú vállalkozásokká fejlődtek, így már nem csak Shared Service Centerek, de üzleti folyamatokat szolgáltató Business Process Outsourcing vállalatok és globális üzleti szolgáltatót, azaz Global Business Centerek is müködnek.

A tudatosan átszervezett struktúrára alapozó vállalkozások müködésének elméleti és munkaerőpiaci hátterét nemzetközi tanulmányok segítségével vizsgáltam, mely vizsgálat során a legföbb kérdések a 21. századi technológiai változásokra és a telephely-átszervezésre gyakorolt általános hatására irányulnak, illetve arra, milyen adottságokkal rendelkezik a befektetői szempontból ideális célország.

A hazai SSC szektor vizsgálatánál a hazai szolgáltatóközpontok jelenlegi számát és fejlettségét, valamint az ország előnyeit és hátrányait vettem figyelembe a visegrádi országokhoz, mint versenytársakéhoz mérten.
\end{abstract}

\begin{abstract}
The political revolution and the multinational companies' entry in the European market restructured the conception of economic culture since it made it possible to work together globally. At an early stage, Shared Service Centers provided low added-value operations and as the organizations started to grow and develop, the added-value also has changed the same
\end{abstract}


way. Advanced service centers offer higher added-valued services and mostly operate in more countries at once, sharing the main functions between the mother company and the subsidiaries. In our days we can recognize Business Process Outsourcing and Global Business Centers beside Shared Service Centers.

The main purpose of this paper is to recognize both the size and maturity of the Hungarian SSC sector. I compared Hungary's current competitiveness, its advantages, and its disadvantages to the Visegrád Group, as primary opponents. By the same token, I studied the common terms of the given areas where SSCs were based, which by Poland, the Czech Republic, Slovakia, and Hungary are positioned in the recent years as high ranked destinations.

\section{Bevezetés}

Az SSC-ket (Shared Service Centers) egyetlen elfogadott definíció hiányában leginkább müködésük, fejlettségük és kiszervezettségük nyomán lehet meghatározni. Az osztott szolgáltatásokat Bryan Bergeron a következőképp fogalmazza meg: "Együttmüködési stratégia során a már létező üzleti folyamatok egy része egy új, önálló egységben koncentrálódik, melyben önálló menedzsment jött létre a költséghatékonyság, értékteremtés és magas minőségü szolgáltatások biztosítása érdekében az anyavállalat és más piaci szereplők számára egyaránt.”1 Az, hogy egy vállalkozást milyen tulajdonságai nyomán lehet szolgáltatóközpontnak nevezni, az nagyban múlik azon, hogy maga a szervezet miként lép piacra, milyen vállalati struktúrát alakít ki és milyen szinten képes elnemzetköziesedni. Azok a szolgáltatók ugyanis, akik kizárólag egy kisebb területen belül, adott városban, legfeljebb országban tervezik megtartani a befolyásukat és hatáskörüket, azok nem nevezhetőek SSC-nek, ezt a vállalati formát a funkciók megosztása, kitűzött hosszútávú céljaik valamint a ráutaló magatartásuk definiálja SSC-nek.

Magyarországon is jelentős fejlődésen ment keresztül a szektor, a foglalkoztatottak száma 2020 első negyedévében megközelítette a 64.000 főt, 2019 azonos időszakában az 55.000 fős létszámot lépte át az iparág hazánkban ${ }^{2}$, ezzel egy év alatt legalább 20\%-kal nőtt az SSC-ben dolgozók száma. A növekedés és fejlődés fenntartása érdekében érdemes azonban megvizsgálni az ország jelenlegi helyzetét a nemzetközi SSC piacon, és a meglévő eszközrendszerét.

\footnotetext{
${ }^{1}$ Bryan Bergeron- Essentials of Shared Services 2003, 3.oldal, saját fordítás

${ }^{2}$ HIPA, Business Services Report Hungary, 2019 https://hipa.hu/images/dokumentumok/hipa-hoabusinessservices-hungary-2019-survey.pdf
} 


\section{Lokalizációs kérdések az SSC szektorban}

A szolgáltatóközpontok létrehozása hosszútávú befektetés az anyavállalat szempontjából, ezért mindenképp fontos az, hogy egy-egy új központ létesítése az elvárásoknak megfelelő körülmények között és olyan helyszínen történhessen meg, ahol biztosítani tudják a megfelelő gazdasági, politikai, jogi és digitális környezetet.

A legáltalánosabb tényezők, mint a megközelíthetőség, infrastruktúra és a megfelelő méretű épület mellett olyan, közvetlen anyagi vonzattal nem járó feltételek is megszabhatóak, amik a zavartalan müködést és a fejlődési, fejlesztési célkitüzéseket is képesek támogatni. Ezek lehetnek a szakmai utánpótlást biztosító egyetemek és képzési központok, vagy azon vállalatok müködése az adott területen, akik potenciális partnercégek, vagy hasonló tevékenységet végeznek.

Egy új országba telepítéskor a legfontosabb szempont az értékteremtés. Az új központ helyszínének megválasztásakor ezért érdemes figyelembe venni a szervezet elsődleges célját, amelyek általában a szervezet méretében, munkavállalóinak számában vagy az elsődlegesen ellátott folyamatok számában okoz jelentős változást.

Jellemzően olyan egységeket hoznak létre, ami az adott térséghez képest előrelépést mutat. A humán tényezőkön felül, mint a szakképzettség és a megfelelö tudással rendelkező munkaerő meglét, más szempontokat is figyelembe vesznek egy potenciális célország vizsgálata során: az ország gazdasági lehetőségei, piacának telítettsége és a müködést terhelő adók és járulékok kivetése. Az európai célországok mindegyike képes már teljesíteni a legalapvetőbb kritériumokat, de eltérő okok miatt választják a vállalkozások szolgáltatóközpontok helyszínéül őket.

A döntést befolyásolhatja a fogadóország konkrét földrajzi helyzete és a városainak minősítése is. Befektetők szempontjából ugyanis az egyes városok hasonlóan elemezhetőek, mint a beszállítók. Az indiai ${ }^{3}$ és kínai ${ }^{4}$ besorolásának mintájára új központ létesítésének tervezésekor is osztályozhatóak a városok, aszerint, hogy gazdasága mennyire aktív, milyen a népességének összetétele és az életszínvonal. Ez alapján alapvetően első (T1), másod (T2) és harmadszintü

\footnotetext{
${ }^{3}$ Dezan Shira \& Associates India Briefing- India's Tier 2 and Tier 3 Cities: Are They Right for Your Business? 2018/01/11, Ramya Boddupalli https://www.india-briefing.com/news/india-tier-2-tier-3-cities-right-business15932.html/

${ }^{4}$ Dezan Shira \& Associates China Briefing- China's City-Tier Classification: How Does it Work? 2019/02/27

Dorcas Wong https://www.china-briefing.com/news/chinas-city-tier-classification-defined/
} 
(T3) települések különböztethetőek meg az SSC szektorban. Első szintűek azok a metropoliszok, amelyek területileg és a demográfiai adatokat tekintve is nagyvárosoknak, fejlettek és gazdasági, pénzügyi vagy számítástechnikai szférában világszinten kulcsfontosságú szerepet töltenek be. Másod, azaz T2-es szintü valamennyi közepes méretü város, ahol jelentős mértékben müködnek shared service vagy global business service centerek, folytatnak kutatásfejlesztést és informatikai tevékenységet, mind belső, mind külső partnereiknek szolgáltatnak, vagy ő maguk is kiszerveznek bizonyos tevékenységeket alacsonyabb szintü (T3) városokba, ahol legnagyobb arányban még az alacsonyabb hozzáadott értékkel bíró feladatokat végzik többségében és gazdaságilag nem kiemelt területeken fekszenek. Utóbbi területeken a legalacsonyabb feltehetően a befektetések összege, ugyanakkor kulcsfontosságú ezen perifériák megtartása és felzárkóztatása annak érdekében, hogy az egyes szolgáltatóközpontok működése megfelelő legyen üzletmenet-folytonossági szempontból.

Az adott helyszín szempontjából megvizsgálható, hogy azok mennyire koncentráltak. Ezt leginkább az ott elérhető és foglalkoztatott munkaerő, és más hasonló vállalkozások megléte mutatja ki. A sűrüsödés-vizsgálatoknál gyakran használt mutató a foglalkoztatási adatok esetében a lokációs hányados (location quotient- LQ) ${ }^{5}$, ami a gazdasági tevékenység egy adott térség gazdaságában való alul- vagy túlreprezentáltságának statisztikai mérőszáma. Egy konkrét helység esetében ez a vizsgált szektorban dolgozó átlagos létszám és elérhető munkaerő hányadosát viszonyítja az országos létszám és munkaerő arányához. A mutató 1-nél nagyobb értéke azokat a térségeket jelzi, amelyekben az adott ágazat az országoshoz viszonyítottan relatíve több foglalkoztatottat képes felmutatni. ${ }^{6}$

Az eltérő preferenciákat figyelembe véve a vállalkozások telephelyválasztása összességében tehát sokféleképpen mérhető. Az amerikai A.T. Kearney által összeállított 50 országot felsorakoztató listán azonos mutatók alapján alakították ki a sorrendet. ${ }^{7}$ A mutatószám a Global Services Location Index elnevezést kapta, ami 4 eltérő területet vizsgál a kiválasztott országok esetében, abból a célból, hogy hiteles és áttekinthető forrásként szolgáljanak a befektető cégeknek. A listán szereplő országok pedig egy külső szemlélet alapján információt kaphatnak a megítélésükről a felmérésben szereplő szempontok szerint. A különböző országok, amelyek valamely releváns szempont alapján egy csoportba oszthatóak, összehasonlíthatóvá válnak akár

\footnotetext{
${ }^{5}$ Szakálné Kanó Izabella- A gazdasági aktivitás térbeli eloszlásának vizsgálati lehetősége, Statisztikai Szemle, 89. évfolyam 1. szám (2011)

${ }^{6}$ ABSL - Business Services Sector in Poland 2018, 18-21.o. alapján

${ }^{7}$ Digital resonance: the new factor influencing location attractiveness - The 2019 Kearney Global Services

Loction Index, https://www.kearney.hu/digital-transformation/gsli/2019-full-report
} 
egyetlen GLSI tényező alapján is, azonban minél több olyan terület van, amely alapján országok vagy országok csoportjai összehasonlíthatóvá válnak, annál valósabb képet mutatnak az aktuális helyzetükről. Ezek a szempontok sorra a pénzügyi vonzerő (35\%), munkaerő (25\%), üzleti környezet (25\%), és digitalizáció (15\%).

A felmérés minden esetben az országok átlagos teljesítéseit és elért eredményeit veszik figyelembe, de kiemelten kezelik a fővárosokat és fejlett ipari területeket. A befektetők számára egyfajta ajánlás, több hasonló elemzés és kutatás végeredménye, hogy a befektetés végül hol valósul meg. A megítélés nem teljesen objektív, tekintve hogy kizárólag amerikai közgazdászok és elemzők vesznek részt a kutatásban, így a megfigyelés szempontjai is az amerikai módszerek és meglátások alapján történik. Jelentős részben külső megfigyelőként az országok valós teljesítményét veszik figyelembe, és érezhetően egyik terület sincs szembetűnően túlreprezentálva.

1. ábra: Összesített GSLI eredmények ${ }^{8}$

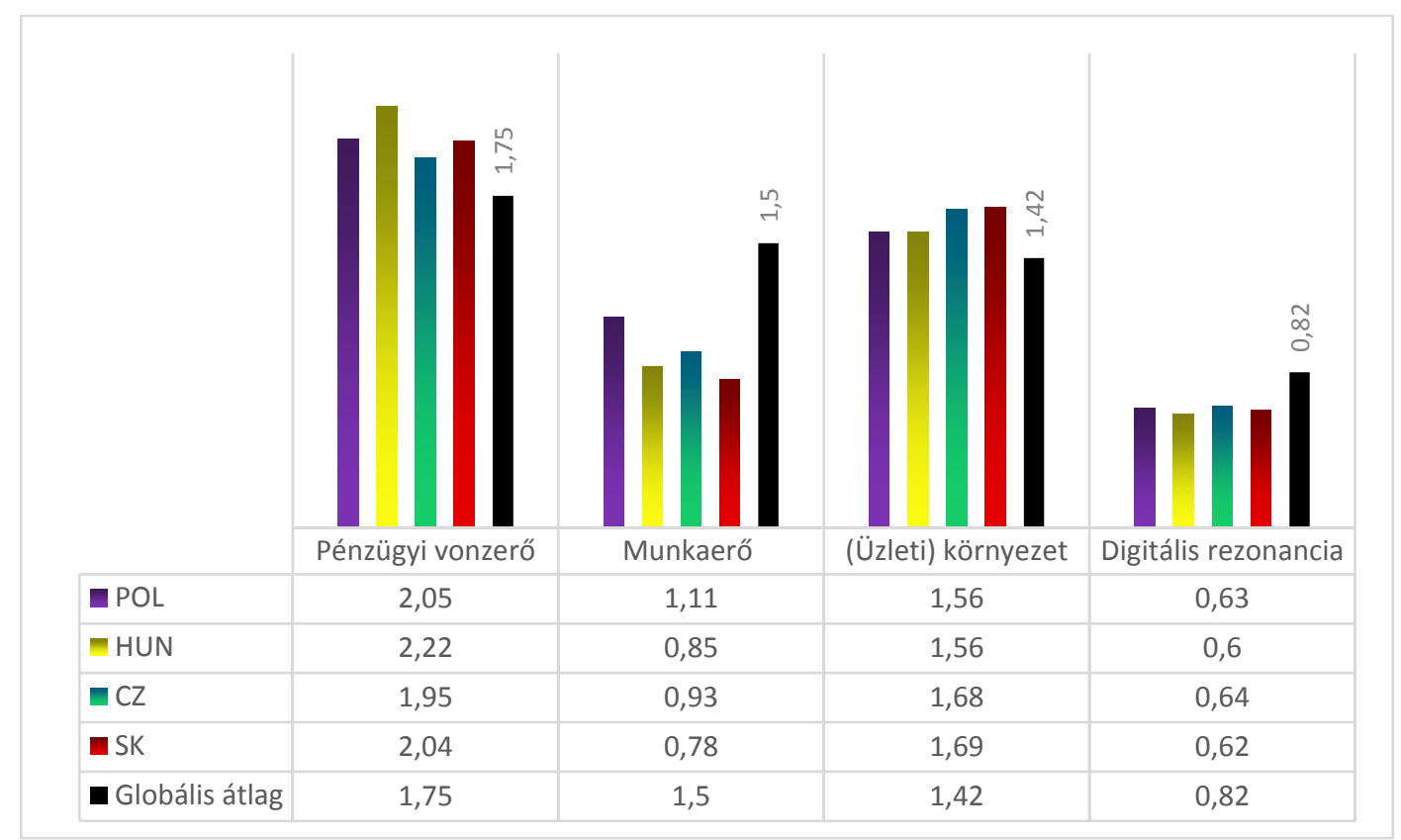

A globális átlaghoz ${ }^{9}$ képest a visegrádi országok nagyon hasonló eredményeket értek el. A munkaerő és digitalizáció viszonylatában mind a négy ország kissé alulteljesít. A másfél pontot megközelítő, 1,495 átlagpontszámhoz képest a legjobb eredményt Lengyelország érte el 1,11

\footnotetext{
${ }^{8}$ Digital resonance: the new factor influencing location attractiveness, The 2019 Kearney Global Services Location Index, https://www.kearney.hu/digital-transformation/gsli/2019-full-report

${ }^{9}$ A globális átlag a felmérésben szereplő 50 ország eredményeinek átlaga
} 
ponttal, ami 0,385 ponttal alulmarad a középértékhez képest, Szlovákia viszont mindössze 0,78as eredménye az átlagnak mindössze a felét haladja meg. Ennek oka, hogy nem kizárólag minőségi, hanem mennyiségi hátránnyal is küzdenek az országok jelenleg. A folyton bővülő piac és az éves szinten több ezer új munkaerő bevonása az SSC-kben még nem érte el azt a szintet, hogy olyan széleskörüen ki tudják szolgálni a partnervállalkozásokat, mint amilyen ütemben más szempontok alapján fejlődni képesek.

A digitális együttható tekintetében az átlaghoz közeli, de az alatti eredményeket értek el, átlagosan a középérték 75\%-át. Ez abból a szempontból fontos, hogy a visegrádi országok előtt áll a lehetőség, hogy ezen az értéken jelentős mértékben javíthassanak az elkövetkezendő években. A digitalizáció ugyanis kiemelt fontosságúvá válik szinte minden szegmensben, és a versenyképesség megtartásának egyik kulcstényezője lehet a jövőben. A digitalizáció terén sok újdonsággal kell szembenézniük a szolgáltató központoknak, annak ellenére, hogy digitális érettségük magasabb szinten van más ágazatokhoz viszonyítva, tekintve, hogy már megalakulásukkor megoldásokat kell találniuk a kommunikáció és az ügyvitel megfelelő platformokra tereléséhez, hogy a tér- és időbeli eltolódások ne okozzanak fennakadást a mindennapi müködésükben.

\section{Kelet-Közép Európa}

A cseh, lengyel, szlovák és magyar szektor a méretkülönbségek és a fejlettségi szint ellenére hasonló tendenciákat követve, egymással versenyezve, mégis egymást segítve fejlődik. Az ABSL (Association of Business Service Leaders), a SARIO (Slovak Investment and Trade Development Agency) valamint a HIPA (Hungarian Investment Promotion Agency) és a velük együttmüködő SSC és GBS vállalkozások által készített tanulmányok nyomán a négy ország mindegyikének más-más erőssége van, ám mivel a tanulmányban érintett SSC vállalkozások jelentős többsége mindegyik vizsgált országban müködik valamilyen formában, így a különbségek az egyes ágazatokban kiegyenlítődhetnek. Az elemzések főbb kérdéskörei, a vizsgált országtól függetlenül, 4 csoportra oszthatóak. Kitérnek a munkaerőpiacra, a technológiai és automatizációs helyzetre, üzleti környezetre, valamint a jövő munkavállalóira. Az ezek általi előnyök és a hiányuk okozta kihívások mindegyik ország esetében hasonló következtetésekhez vezetnek. Ennek nyomán a következő törekvések kerülnek fókuszba: a fenntartható növekedés és fejlődés mellett a megfelelő képzettséggel rendelkező munkavállalók toborzása és megtartása a szektorban, a fluktuáció elfogadható mértéken tartása, valamint a kiemelkedő helyszínek és az ebből a szempontból peremvidékek közti különbség csökkentése. 
Ezek a kihívások különböző mértékben érintik az országokat, eltérő helyzetük és erősségeik miatt. Vagyis egy konkrét példával élve: a fővárosközpontú Magyarország telephely-kérdései eltérnek a nála jóval nagyobb méretü piacot fenntartó Lengyelországétól, de mindkét ország SSC szektorára hatással van az egyre telítettebb ingatlanpiac.

A lengyel SSC szektor jövőjét a 2019-es ABSL tanulmányban publikált GBS 2.0 határozza $\mathrm{meg}^{10}$. A legnagyobb európai SSC szektorral rendelkező országa, a SSC,BSC és BPO vállalkozások által foglalkoztatottak száma meghaladja a 320000 föt. A még nem hivatalos új forma az eddigi SSC-jelelegü vállalkozások fejlettségét átlépő, Global Value Organisation. A szervezeti egység ezen a szinten már nem csak globális szolgáltatóként, de globális értékteremtőként jelenik meg. Müködésének alapjait a digitalizációra és az ellátási láncra helyezi, a mesterséges intelligencia segítségével pedig egyedülálló informatikai és pénzügyi megoldásokat képes nyújtani.

Ennek elérését az 5E megközelítés segíti. A láthatóvá tétel (envision) és a lehetővé tétel (enable), és a végrehajtás (execute) az adatok vizuális megjelenítésére utaló komponensek. Eszközeik segítségével lehetővé teszik a magas komplexitású és nagy mennyiségü adatok feldolgozását, amelyek a meglévő adatbázis menedzsment eszközökkel jelentős nehézségekbe ütközik. A világszerte és napi szinten előállított óriási adatmennyiség és azok sebességéből fakadó kihívásokra kínálhatnak megoldást. Az ökoszisztéma (ecosystem) a természeti és fizikai környezethez való alkalmazkodás mellett a különböző területek és szervezeti egységek együttműködését képviseli. Az osztott szolgáltatások rendszerében a különböző helyszínekre kiszervezett folyamatok esetén is megfigyelhetőek a távolság ellenére az összefonódások, a különböző területek szimbiózisa. Ezek a kapcsolatok alapvetően szükségesek a fejlődés fenntartása érdekében. A növekedés (expand) pedig mindezen faktorok segítsége mellett valósulhat meg. A növekedés, mint piaci jelenség és mint méretbeli növekedés is jelen van a GBS 2.0 esetén. Az egyes központok által végzett tevékenységek kiterjesztése és a szektorban dolgozók létszámának emelkedése és a minőségbeli javulás egyaránt beletartozik.

A globális szervezet eléréséhez szükséges innováció finanszírozására kialakított modell a különböző területekbe befektetett pénz és fejlesztés arányát határozza meg. A müködési költségek 70, a folyamatfejlesztés 20, a digitalizáció és innovációs tevékenységek pedig 10\%os arányban jelennek meg a teljes költségvetés tekintetében. Az SSC szektor szempontjából

\footnotetext{
${ }^{10}$ ABSL Business Services Sector in Poland, (2019) „GBS As A Transformation Engine”
} 
fontos területek behálózzák az ország teljes egészét, így az 5E és a digitalizáció is elősegíti, hogy Lengyelország kiemelten fontos desztináció és központ lehessen az európai piacot tekintve. Fejlesztései és kiszervezései pozitív hatással lehetnek a környező országokra is, akár a munkaerő allokációt, akár az üzleti folyamatok átvételére vonatkozóan. Tekintve, hogy az országhatárok egyáltalán nem jelentenek hátrányt kereskedelmi és szolgáltatói szempontból, cégcsoporton belül a szabadalmak és az eljárásrendek szabadon átültethetőek egy cseh, szlovák vagy magyar központba is, miután a lengyel központban sikeresen alkalmazzák.

Szlovákia első számú célkitüzései közt szerepel a magasabb hozzáadott értéket teremtő szolgáltatóközpontok létrehozása és betelepítése, mint az informatikai, SSC és kutatásfejlesztéssel foglalkozó cégek. A Szlovák Köztársaság a különböző SSC-k és BPO-k létrehozásának támogatása érdekében olyan intézményi stratégiát dolgozott ki, ami jelentősen növelheti az ország megítélését európai szinten.A cél a növekvő aktivitás az iparágban, a létesítmények számának és minőségének emelkedése ${ }^{11}$. Az Institutional Strategy for Business Service Centers Development in Slovakia ${ }^{12}$ elnevezést viselő intézkedésnek három, egyformán fontos és hangsúlyos alappillére van. Az egyike ezeknek a munkaerő. Az ország maga is biztosítani kívánja a megfelelő képzettségü munkaerőt és olyan képzési- és továbbképzési rendszert kíván kialakítani, ami a jövőben is kielégíti a BSC-k és más nagyvállalatok humánerőforrás igényeit. Emellett támogatja a már meglévő vállalatok edukációs célkitűzéseit.

Az ABSL a Cseh Köztársaság esetében külön tanulmányban igyekszik kivetíteni az ország lehetőségei 2025-re ${ }^{13}$. A Deloitte-tal közösen elvégzett kutatások 4 fókuszt kiemelve vizsgálták az ország jelenlegi helyzetét a már meglévő adataik és a cseh SSC szektor tapasztalataira alapozva. A technológiai fejlődés az adatok digitalizálását, az élő munka és a szoftverek szinergiáját és az adatvédelmet emelte ki leginkább. A munkaerővel kapcsolatos felvetések részben ehhez kapcsolódva merülnek fel, de fontos szerepet kaphatnak majd az edukációs törekvések, a belső mobilitás és munkakörváltás, valamint az együttmüködés mind oktatási intézményekkel mind saját iparágukban müködő más vállalkozásokkal. A HR stratégia

\footnotetext{
${ }^{11}$ Shared Services \& Business Process Outsourcing Centers in Slovakia https://www.sario.sk/sites/default/files/content/files/sario-ssc-bpo-centers-in-slovakia-2018-0920.pdf

${ }^{12}$ Intézményi stratégia a szlovák Business Service Centerek befektetése érdekében

${ }^{13}$ ABSL Czech Business Services-Our Vision 2025(2018) alapján, saját szerk. https://www.absl.cz/wp- content/uploads/2018/ABSL_Vision_2025_brochure_e-version.pdf
} 
leginkább meghatározó eleme a meglévő munkaerő képzése, akár saját területükön belül a digitalizáció okozta megváltozott helyzetre reagálva, akár szélesebb körben értve.

A fejlődési irány emiatt eltér a környezö országokétól. Szlovákiával szemben rövidtávon nem a digitális és FinTech irányba kíván elmozdulni a cseh SSC piac, hanem a már meglévő kompetitív előnyöket képző funkciókat kívánják magasabb szintre emelni. A jövőbeli müködés kérdései közt szerepel az automatizáció, de megoldásra vár még az országban a sztenderdizáció is és az optimalizáció, ezért ez egy távolabbi cél. A jövőbeli kihívások a HR területére, a gazdasági környezetre vonatkozóan a technológia változásából fakadnak. A Cseh Köztársaság esetében az elkövetkezendő években így előreláthatólag nem az lesz a meghatározó, hogy az új belépök számát és a befektetéseket növeljék, sokkal inkább az, hogy a jelenlegi SSC-k által végzett munkák magasabb szintre léphessenek és a mennyiségi növekedést felváltsa a minőségi elörelépés.

Magyarországon 104 szolgáltató központban és azok leányvállalatainál, 119 helyszínen, 22 iparágat érintve 63,800 föt foglalkoztatnak SSC-ben.

Habár a szolgáltatók központja elsősorban a fővárosban és vonzáskörzetében vannak jelen, az egyetemi városok és iparterületek vonzáskörzete is egyre népszerübbé válnak. Kiemelkedő, 80 százaléknál is magasabb arányban müködnek a fővárosban szolgáltatóközpontok, emellett Székesfehérvár, Debrecen, Pécs, Szeged és Miskolc területén müködnek hasonló vállalkozások. Ezekben a városokban egy, vagy több egyetem is müködik, a megközelíthetőségük és a kiépített infrastruktúra megfelelő, a jelenlévő munkaerő pedig alacsonyabb költséget jelent, mint a fövárosban.

Magyarországon olyan meghatározó össz-szektori célkitüzések egyenlőre nincsenek, mint a többi országban. A magyar SSC szektor jövőjét is leginkább az határozza meg, hogy a már müködő vállalkozások hogyan fognak alkalmazkodni a megváltozott igényekhez és környezethez. A hazai BSC-k 79\%-a rövidtávon a magasabb értékteremtést tüzte ki célul a hatékonyság, minőség, ügyfélélmény és automatizáció terén, és 73\%-uk újabb funkciókat helyezne át a cégcsoportok belülről a magyarországi központokba ${ }^{14}$ A fejlődő szolgáltatóközpontoknak kevesebb, de magasabban képzett munkaerőre van szükségük a

\footnotetext{
${ }^{14}$ HIPA, Business Services Report Hungary, 2019 https://hipa.hu/images/dokumentumok/hipa-hoabusiness- services-hungary-2019-survey.pdf
} 
hatékony és jó müködéshez, így ez a fókusz magába foglalja a munkaerő továbbképzését és a megfelelő képzettséggel rendelkezők felkutatását a szabadon lévő posztokra.

\section{Összefoglalás}

A szolgáltatóközpontok jelenleg növekvő fázisban vannak egész Európában, a meglévő vállalkozások jelenlegi központjukat részben kiszervezve, részben továbbfejlesztve kívánják a jövőben müködtetni. Az országok tekintetében a legnagyobb verseny a befektető cégek miatt alakul ki, ugyanis a célországban befektetők hosszútávon gondolkodó vállalkozások. Meglétük és a folytatott tevékenységük további előnyökhöz juttathatják az adott tagországot: hasonló vállalkozások befektetései, meglévő társaságok fejlesztéseinek pozitív hatása az ország gazdaságára, valamint a több ponton összefonódó alaptevékenységek is befolyásolhatják a jövőbeni új belépőket. A kapcsolattartás és a napi munkavégzés teljes mértékben digitalizált a támogató területeken. Az informatikai rendszerek és azok fejlődése elválaszthatatlan elemévé vált a kereskedelmi, számviteli és egyéb üzleti folyamatok szempontjából.

A visegrádi országok mindegyikében hasonló fejlődési szakaszok és stációk figyelhetőek meg. A lengyel, cseh, szlovák és magyar SSC szektor az 1990-es években kialakulva mára egy dinamikusan fejlődő, adaptív szektorrá vált. A legalapvetőbb ügyfélszolgálati és riportolási feladatokat végző cégek globális üzleti központok, HR, pénzügyi és informatikai GBS vállalkozásokká fejlődtek. Az eltérő célkitüzések és fejlettségi szint ellenére mind a négy országban hasonló kihívásokkal néz szemben a szektor, amit leginkább a digitalizáció és a munkaerőpiac jövőbeli alakulása vet fel. A prognosztizált fejlesztések, az előrelépést támogató stratégiák már nem elsősorban a bevételnövekedést támogatják a visegrádi országokban, hanem a már meglévő SSC-k előrelépését és az új belépőknek kedvező környezetet kívánnak kialakítani.

Az egyfókuszú SSC-k fejlesztését és az új belépők átlagos mértékét tekintve megoldás lehet az ország számára a másodszintű városok jelentőségének növelése, ahol eddig még nem, vagy csak operatív jelleggel voltak jelen ezek a vállalkozások. Ha a legalapvetőbb szempontoknak megfelelnek, azaz van elérhető, képzett munkaerő, a gazdasági és politikai környezet stabil, és a működés szempontjából nem jelent hátrányt, akkor a leadható háttértámogatói feladatkörök ott müködhetnének tovább, míg a főváros terheltsége csökkenne és a központok magasabb szintre léphetnének. a reorganizációs folyamat mindkét oldal számára pozitív lehet: 
a vidéki központok alacsonyabb költséget jelentenének a müködést tekintve, az újonnan bevont városokban pedig kiépülhetne a megfelelö infrastruktúra ahhoz, hogy a jövőben is müködőképesek lehessenek a multinacionális vállalatok. Az oktatási intézményekkel történő együttmüködés pedig megalapozhatja az SSC-k jövőbeli munkaerővel kapcsolatos igényeinek kielégítését. 


\section{Felhasznált irodalom}

1. (ABSL), A. o. (n.d.). ABSL - Business Services Sector in Poland 2019. Retrieved from https://absl.pl/storage/app/uploads/public/5d0/7a1/406/5d07a140668f0191663458.pdf

2. (ABSL), A. o. (n.d.). https://www.absl.cz. Retrieved from ABSL CZ Publications: https://www.absl.cz/wp-content/uploads/2018/ABSL_Vision_2025_brochure_eversion.pdf

3. Agency, H. I. (n.d.). HIPA Business Services Repoprt Hungary 2019. Retrieved from https://hipa.hu/images/dokumentumok/hipa-hoa-businessservices-hungary-2019survey.pdf

4. Association of Business Service Leaders (ABSL)in cooperation with:JLL, R. P. (n.d.). Business Services Sector in Poland, 2018. Retrieved from https://absl.pl/storage/app/uploads/public/5e2/573/bf2/5e2573bf23a98958162901.pdf

5. Bergeron, B. (2003). Essentials of Shared Services.

6. Dorcas Wong, D. S. (2019, február 27). China Briefing. Retrieved from https://www.china-briefing.com/news/chinas-city-tier-classification-defined/

7. Izabella, S. K. (n.d.). A gazdasági aktivitás térbeli eloszlásának vizsgálati lehetôségei. Statisztikai Szemle, 89. évfolyam 1. szám.

8. Kearney, A. (2019). Global Services Location Index, Digital resonance the new factor influencing location attractiveness the new factor influencing location attractiveness The 2019 Kearney Global Services. Retrieved from https://www.kearney.com: https://www.kearney.hu/digital-transformation/gsli/2019-full-report

9. Ramya Boddupalli, D. S. (2018, január 11). India Brefing. Retrieved from https://www.india-briefing.com/news/india-tier-2-tier-3-cities-right-business15932.html/

10. SARIO. (2018, 09 20). Shared Services \& Business Process Outsourcing Centers in Slovakia. Retrieved from https://www.sario.sk/sites/default/files/content/files/sariossc-bpo-centers-in-slovakia-2018-09-20.pdf 